Kohl: a Journal for Body and Gender Research

Vol. 4, No. 1 (Summer 2018)

\title{
States of Wait: The Death Penalty in Contemporary Egypt
}

\author{
Amira Mahmoud Othman
}

\begin{abstract}
:
This paper is an exploration of the daily encounters of "political" prisoners on death row ward with figures of the state. Building on ethnographic fieldwork and theories around states, bodies, terrorism, law, and fantasies, the paper problematizes the contemporary state discourse on "terrorism." Instead, it proposes an understanding of the state's creation of gendered "terrorist" bodies, which it deems killable in the process. Meanwhile, it identifies the state as heterogeneous, and acknowledges the multifaceted manifestations of the contemporary Egyptian state in the everyday encounters with death row inmates and their families. It also explores the inevitable wait for the state in every process, thereby taking seriously the realm of temporality on death row, and what it then means to refuse to wait.
\end{abstract}




\section{Background}

On 12 August, 2012, former president Mohamed Morsi appointed Abdel Fattah El Sisi (Egypt's current president) as minister of defense. On 3 July 2013, Sisi was involved in a military coup that toppled Morsi, in response to protests on 30 June 2013 - a year after Morsi was elected. Sisi appeared once more, on 24 July 2013 , asking "the people" for a "mandate" to combat terrorism. ${ }^{1}$ The following crackdown on the Muslim Brotherhood culminated in the (14 August 2013) Rabaa massacre, in which hundreds of civilians were killed and thousands injured. On 26 March 2014, Sisi announced his retirement from the military in order to run for presidency. He became Egypt's sixth president on 8 June 2014, pledging that the Muslim Brotherhood "will not exist"2 thereafter. In August 2015, Sisi passed a "deeply flawed" counter-terrorism law, as described by Amnesty International, ${ }^{3}$ allowing him to "take extreme measures that would usually only be invoked during a state of emergency." This law stipulated the use of the death penalty for at least 15 crimes, including funding a terrorist group or terrorist act; manufacturing weapons; damaging a gas, water, or electricity network; or compelling another person to join or remain in a terrorist group, if they result in (unintentional) death. The pretext of such crimes is, as described by Human Rights Watch, "a definition of terrorism that is so broadly worded it could encompass civil disobedience."

Within the context of combating terrorism, this paper is an exploration of the everydayness of the death penalty following crimes put forward in Sisi's counterterrorism law. Hence, it is an unfolding of abstract notions such as state, terrorism, law, and time, by focusing on the daily encounters with death row detainees, their families, and figures of the state. As an inquiry into the production of killable bodies within contemporary Egypt's highly charged political spheres, this paper is based on a nine-month ethnography with some family members of death row detainees in Egypt. The family members of 10 men sentenced to death in five "political" cases, aside from court documents and video footage in which the encounters and articulations of four other men in other political cases, comprise the ethnographic material of this paper. Their articulations are put in conversation with other theoretical fragments, in an attempt to intricately trace these ethnographic encounters as they speak to conceptual frameworks in anthropological literature: on states, bodies, violence, fantasies, terrorism, and imaginaries. What follows is an identification of the different forms - or faces - of the "state," as they make themselves known within the realm of the death penalty. Afterwards, the paper attempts to take seriously the conception of temporalities, by speaking to the torture of waiting for the state, and the potential of no longer waiting.

Furthermore, the paper problematizes the (dominant, yet perhaps simplistic) association of the category of "gendered" bodies with "female" bodies. Instead, it hopes to endeavor through further layers of such category, by pushing for a gendered analysis of certain male bodies. While the aggravated state violation of women's bodies cannot be overlooked, this research is based on bodies sentenced to death in cases

1 http://english.ahram.org.eg/NewsContent/1/0/77314/Egypt/0/Egypts-presidency-calls-for-protests-against-terro.aspx

2 http://www.bbc.com/news/av/world-middle-east-27289931/egypt-election-sisi-vows-end-to-muslim-brotherhood

3 https://www.amnesty.org/download/Documents/MDE1222692015ENGLISH.pdf

4 https://www.hrw.org/news/2015/08/19/egypt-counterterrorism-law-erodes-basic-rights 
dubbed political - all of which are male bodies. Although the same standard of comparison do not apply, no "woman" 5 was sentenced to death following such "political" case throughout the duration of ethnographic fieldwork for this paper, ${ }^{6}$ as women's bodies in jail are largely treated as depoliticized by mainstream narratives. Within a counter-terrorism state discourse, the scope of this paper thus proposes the understanding of the state's production of killable bodies as a gendered process, in which encounters with the heterogenous state - within a "counterterrorism" context - are quite deadly.

\section{Not Just One State}

The "state" as such continues to be problematized as both an abstract, conceptual category and a very much present, almost tangible entity. From an anthropological perspective, this paper explores the multifaceted, non-singular, and inexplicable thing-cum-state, as encountered, articulated, and described by the family members of some of the people sentenced to death in contemporary Egypt. It follows Das' (2004) interest in the everyday, and builds upon the increasing scholarship on affect to explore the Egyptian state as an emotional stimulus and visceral reaction trigger in an arena where life and death are granted, constituted, and entangled with stenches of sovereignty and games of law. In this framework, the state in/of Egypt is arguably masculine, lazy, "paranoid," maddening, intentionally irresponsible, papercentric, and by all means precarious. That is to say, all these different forms of the state could be seen and to some extent felt - in the everyday as the multiple faces of a state-Janus (Trouillot, 1991, p.28).The "everyday" is increasingly engaged in recent anthropological literature on the "state" (Das, 2004; Trouillot, 2001). The utilization of concepts such as "biopower"7 and "governmentality"8 are made in such light, to allow for a rethinking of the "state" as a phenomenological reality that is constituted through discourses and power practices at the level of the everyday (Foucault, 1984; Aretxaga, 2003, p.398). Practices and discourses around the death penalty in Egypt indeed reveal the extent to which the state is "implicated in the minute texture of everyday life" (Gupta, 1995, p.375), under claims of safety, security, and infinitely imminent threats. The state's effects are to be felt in every process leading up to the possibility of taking lives under pretexts of countering terrorism and establishing sovereignty (Trouillot, 2001, p.126), thereby producing killable bodies and simultaneously establishing its authority over the management of life and death (Agamben, 1998).

\section{The Lazy State}

5 That the author knows of.

${ }^{6}$ During summer 2016 to winter 2017.

7 Coined by Foucault, the term biopower simply refers to the power over bodies by the state and its (disciplinary) institutions

8 Also a Foucauldian term, indicating practices and methods of governance and how societies are rendered governable 
In his "The Proper Use of Criminals," Foucault (1994) provides an interesting answer to the question: why are death sentences so easily handed down? The "machine," as he describes the legal system, should generally be extremely careful when deciding whether, and why, certain lives are at stake. However, what we see instead, and it is unprecedentedly obvious in contemporary Egypt, is the influx of death sentences with such an ease and an almost "sleepy gesture" (p.429). It is not one person, or cog, that is such indifferent, but the entire machine: the entire legal apparatus is indolent. It is the "laziness of the investigators, the judges, the lawyers," (p.429) and definitely of the police, that results in staggering death sentences which are built upon very shaky grounds.

The contextual specificity is more telling. Notoriously known as the "death sentences judge," Nagy Shehata appeals to, and speaks in the name of, the "law." He, along with the two other judges on the panel, throw the ball in the Mufti's lap so According to the Egyptian Penal Code, ${ }^{9}$ the court must refer the defendants' "papers" to the Grand Mufti before issuing a death sentence. The same article stipulates that the Mufti's response must reach the court within 10 days with an added Sharia blessing; if not received during the 10day window, the court may issue a death sentence at its convenience. Egypt has only one Mufti, with a panel of five or six appointed "experts" to assist him. Last month alone, he received the papers of at least 54 people in 17 different cases - and this was not even an exceptionally high number: since the beginning of the year, 10 at least 300 case files awaited his signature. In line with Foucault, and as evident by the increasing number of death sentences that the legal system has been handing down, it is practically difficult (if not impossible) to really investigate in only twelve months whether more than 300 people deserve to die, from a position that despite being laden with symbolism, is a paid 8-hour job at the end of the day. And so he signs in $95 \%$ of the cases, out of "trust in the judge, who saw the defendant's facial expressions" and "trust in the Egyptian interrogation procedures," as he himself articulated on TV last October (Sada EIBalad, 2017). In the 5\% margin where he is somewhat reluctant to sign, he throws the ball back to court, choosing to "trust the court's justice" (Sada ElBalad, 2017). Further in line with Foucault, he also signs out of laziness, which is primarily predicated on what Foucault called "the cult of the confession." Perhaps this is the only thing that the Mufti panel look for: whether or not the defendant has confessed to the crime.

This confession cult is particularly interesting as it brings forward the implication of the interrogators whom perhaps none other than the Mufti can claim to trust. Despite their laziness, police members and prosecutors exert quite a lot of physical effort in their extraction of confessions. Why is a confession this important? Why must the defendant be tortured, to the extent that there are identifiable patterns of torture given names - the shawwāya is, for example, a common practice of hanging a person, usually upside down on/near a door for hours - in order to articulate a "confession?" (Human Rights Watch, 2017). And why is such confession so sacred that its existence is enough to blind the entire legal system of anything else, even why and how it was made, and when it was recanted? It is not only needed for the policeaudience, but is often times necessary for a much greater one. The investigators and their collaborators go

${ }^{9}$ Article 381

${ }^{10}$ And until late November 
to further lengths, even after their torture practices, to broadcast these "confessions" - the more the merrier.

The case in which people accused of assassinating the former Public Prosecutor Hisham Barakat is quite telling in that regard. Before the official arrest warrants were made, the Ministry of Interior published a video ${ }^{11}$ showing four people - all of whom were sentenced to death a few months later along with 24 others - claiming to have somehow participated in the murder. One of them later said during court: "The things they wanted me to say were written on three pages of paper. They made me memorize and recite them before a camera. At the time the torture marks were still visible on my face, so they covered them with makeup first." ("In the Name of the People," p.35). The fact that his statement was registered in official court papers, which bore the state seal, was not important. The fact that mattered was that he confessed: the police succeeded in extracting a confession, and their makeup artist was an asset to the team.

In a lazy legal machine, as described by Foucault (1990), such confessions are vital to making everyone's job easier. Perhaps it is bestowed with an element of "fundamental truth" that is uncovered, making people content. Or perhaps it has more religious resonances, manifest in the desire for the criminal to endorse his own conviction. In any case, the confession is "a locus of gentle complicity for all the functionaries of penal justice" (Foucault, 1994, p.430-1).

\section{The "Paranoid" State}

The "extracted confession," along with the lazy legislation, give rise to a form of criminalization discourse that is utilized by the "paranoid" state 12 to judge criminals, not crimes. The crimes, no matter how graphic, are gradually forgotten; the criminal, on the other hand, is always present - until, at least, the state uproots him/her from society, promising to make him/her disappear. This shift towards judging the culprit requires less intellect and money; it seems easier to point to a "criminal" and create an embodiment of evil rather than address societal problems that certain crimes highlight. It is also more satisfactory and easy to understand/pathologize a person than to establish the facts of the crime committed (Foucault, 1994, p.432). The criminal as such is also needed by the press - the figure of evil upon which societal fears and fantasies are directed. Thus the state, through its indolent legal and media apparatuses, invests in creating a criminal profile. Driven primarily by the "confession," the crime is already attached to the person; all that remains is to construct a criminal personality. Already more than 15 crimes set forth by the counterterrorism law are punishable by death. The state must only pronounce the term "terrorism" to enact its fantasies of it. By appealing to such narratives, the state provokes public sentiments such as public safety and security - the

\footnotetext{
11 https://www.youtube.com/watch?v=Zbyvpg4S7BE

12 I use the term "paranoid" as used by Aretxaga (2003) to denote the "paranoia" at play by the state in counterterrorism contexts. In this sense, the death penalty is used by the state in enactment of "paranoia," reflecting a "mirroring paranoid dynamic" that manifests as powerful identification and obsessive fascination, hence the engagement in "terrorist" practices to appropriate the power attributed, as in official discourses, to terrorists.
} 
"masās" (harm) is among the 15 killable crimes - to rid the imagined national space of such terrorists (Tambiah, 1997) and hence legitimize their killable status (Arendt, 1953, p.241).

The counter-terrorism narrative, as manifested in Sisi's speeches and slogans, ${ }^{13}$ stirs up discourses of patriotism and war against a "magnified enemy," which necessitates national unity in order to label it as a common enemy-outsider (Aretxaga, 2001a; Zulaika \& Douglas, 1996). A prerequisite for such narrative is the creation - or power imposition - of an expelled outsider. As Agamben (1998) and Turner (1974) explain, the power of the sovereign lies in its monopoly to impose narratives on bodies, thereby constituting them as enemies to the extent that their status as "outsiders" becomes a matter of common sense. The resultant outsider-insider is thus in effect a scapegoat (Girard, 1979), upon which violence within the national community is displaced, and upon whom the state's violence seizes to count as such; rather, the state in this narrative acts as a superhero, portraying itself as responsibly - and graciously - defending the helpless citizen-victims against terrorist-others.

The state-terrorism power dynamics have been analyzed as a "mirroring paranoid dynamic," which takes the form of obsessive fascination for the sake of power appropriation (Taylor, 1997). In this sense, the claims to power are coupled with a show of violence, with an emphasis - on part of the state - of the state's sole legitimacy and monopoly over any and all forms of violence (Arendt, 1953). While deciding that the verdict will be announced during the following court session, Nagy Shehata, famously known as the "death sentences judge," assured the defendants in the "Giza cell case" that he "will not make them wear red," as narrated by the brother of one of the defendants to the author. It so happened that two days before this scheduled verdict, more than 54 policemen were killed in an ambush during a raid southwest of Cairo. ${ }^{14}$ This incident is not irrelevant, for the state's obsession with the figure of the criminal partially has to do with the fact that the criminal mediates a realm of death, which the state - outside the sphere of the death penalty - lacks. Thus, in enacting its sovereignty over the body of the criminal, it hopes to expand its powers over the realm of death as well (Siegel, 1998, p.6).

In this imaginary, both the state and its dangerous other/insider-outsider are co-produced as fetishes of each other, constructing reality as an endless play of mirror images, and the figure of the other as an endless figure of encountered fantasies (Aretxaga, 2003). Journalists alongside judges often turn to fiction while writing about "terrorism," as in the 2014 Minya verdicts in which 529 people were sentenced to death

13 For example, Sisi vowed that the banned Muslim Brotherhood group "will not exist" during his presidential campaign (http://www.bbc.com/news/av/world-middle-east-27289931/egypt-election-sisi-vows-end-to-muslimbrotherhood). He also recently stated that "the danger of terrorism that has become a formidable threat to the peoples of the entire world" at the Arab-Islamic-American Summit in May 2017, before introducing his four-fold counterterrorism strategy (https://enterprise.press/wp-content/uploads/2017/05/Sisi-Speech_RiyadhArabUSSummit2017.pdf).

$14 \quad$ https://www.apnews.com/992e98a32ca14438ba73bb8c1c13b9a1/54-Egyptian-police-killed-in-ambush,-sayofficials 
for having - all 529 - participated in the murder of one man. ${ }^{15}$ Infused within terrorism discourses are unclear boundaries between fiction and reality: encounters between the state and terrorists have "a phantom quality," (Aretxaga, 2001a; Zulaika \& Douglas, 1996, p.14) whereby those identified as the state are simultaneously haunted by the fantasized power of such criminal-terrorists (Aretxaga, 2000a; Taussig, 1986; Siegel, 1998). At the heart of this haunting fantasy is, first and foremost, the realization of the cult of confession.

\section{The Masculine State}

It is interesting to consider another form of "paranoia" as co-existing with the phantom-mirroring dynamic what George Carlin describes as the "prick waving contest" (Henyel, 2014). The war on terrorism, bolstered by the definitely masculine state (Conway, 2008; Aretxaga, 2001), is arguably a competition of establishing "who has the bigger dick" (Henyel, 2014), wherein each party's sexual sovereignty is challenged, and must therefore enact its manhood power fantasies by establishing itself as the sexual sovereign. In this light, the discourse on combating terrorism reflects an underlying premise of a "state in crisis," as used by Conway (2008). In other words, people who ascribe to other/"terrorist" ideologies at the expense of believing in the state's profoundly destabilize the state's gendered binaries upon which claims of nationalism and unity rest. And so the state's multi-propaganda strategies are a) to employ a discourse of heroism, masculinity, and nationalism when commemorating soldier-victims of "terrorist" attacks; b) to immediately respond to such attacks by executing its self-given right to kill; and c) to stigmatize political death row defendants as outsider/others, laden with "feminine" attributes, who do not belong in the (unified) pathway to the future calling instead for their extinction on the premise of a safer, better, "future anterior" rationale (Povinelli, 2008).

This politicization of gendered terminology is obvious in the official press releases by state entities. A 2015 press release by the Ministry of Interior following the tragic murder of a police officer in Beni Suef described him as "the hero martyr, who was martyred in redemption of the nation and in protection of its stability," while the ministry asserted "its continued efforts to pursue and arrest the cowardly terrorist elements that attempt to affect stability and obstruct the march towards progress and development"16 (emphasis mine). Such language choices are in line with Conway's (2008) gendered analysis of state in crisis, to reflect itself as a masculine, heterosexual entity, while maintaining the cowardness of terrorist/others - identified as "elements" - who relentlessly aspire to go against the state's plan to better the "nation."

As for the immediate execution of such labelled outsiders, this has become identifiable starting late December 2017. Since then, mass executions have occurred the day following "terrorist" attacks, with 15

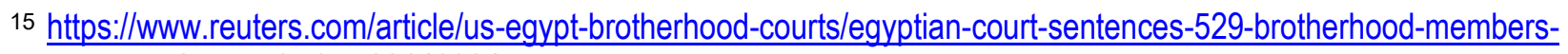
to-death-idUSBREA2NOBT20140324

16 Original press release unavailable; quoted in Al Masry Al Youm at: http://www.almasryalyoum.com/news/details/771410 
people executed on December $26^{\text {th }}$, five more on January $2^{\text {nd }}$ - including some of the people who helped write this paper, 17 three more on January 9th, another person on January 23rd, and again another on January 30th. Early on, at least 12 Egyptian human rights organizations have described this political use of the death penalty, in agony, as "unprecedented in Egyptian history."18

As daunting as it seems, it is perhaps relevant here to ponder on the notion of "intimacy" between the state and those it expels as terrorist-criminal-other (Agamben, 1998, p.110; Berlant, 1997; Siegel, 1998; Zizek, 1993). Threatening the state's heterosexual forms of political control means going against its narrative of sovereignty. It makes sense, then, that the same Nagy Shehata sentenced all 11 defendants in the "Giza cell case" to death, within 24 hours of the Sinai mosque killings. It seems that the question of phallocentric sovereignty is very much invested in the fantasy of right to power over death (Siegel, 1998, p.6). And the idea that killing, on either side, is sexually gratifying, is indeed problematic, perhaps even maddening.

\section{The Maddening State}

The modern management of bodies in general (and the bodies of "the condemned" in particular) (Foucault, 1979; Agamben, 1998), along with the intimacy that makes it possible within the power of the "law," symbolizes and captures the sovereign power of the state. Such sovereignty manifests in the violence of law, with the figure of the police incarnating and investing in its persecutory power: the effects of that haunting figure are readily known and not surprising, but its identity remains mysterious and continues to trigger speculation, fear, and rumor (Benjamin, 1978). All the family members I spoke with always referenced policemen - what division, rank, and state entity they belong to is irrelevant - always as they. When they first came to Lotfy's family house, they cut open a metal lock on a steel gate - the only steel gate in the village. It was long before they found and tortured a confession out of him, therefore sentencing him to death in the "Kafr El Sheikh stadium bombing case." The family fixed the lock on the gate after they left, but again they - the military policemen/officers/bad guys/perpetrators/state-terrorists - kept breaking it, so the family decided to leave it broken. "What's the point?" Sara, his younger sister, asked me, "why should we fix it if they keep breaking it anyway?"

State sovereignty, as practiced by the figure of them, is indeed not an exception, but the rule (Benjamin, 1968, p.257). They are not bound by the law precisely because of their representation of a state of exception, which is decided to affirm a juridical order in which lawfulness and right are suspended in the name of the law. In fact, the execution of the law and its transgression become so indistinguishable that "what violates a rule and what conforms to it coincide" (Agamben, 1998, p. 57). A rule of law beyond the law continues to operate in a scene of their "obscene enjoyment" (Zizek, 1993).

\footnotetext{
17 The four defendants in the Kafr El Sheikh stadium bombing case were executed on January 2, 2018.

18 https://eipr.org/en/press/2018/01/unprecedented-political-use-death-penalty-egyptian-government-will-only-incur- 
Despite its essential emptiness, the "law" engulfs everyone who is not a figure of it, as the epitome of exercising the power over life and death (Agamben, 1998; Benjamin, 1978; Aretxaga, 2003; Taussig, 1992; 1997). It is inescapable and, when one's life is at stake, triggers an "obsessive attempt at interpretation" (Aretxaga, 2003, p.406). In these moments of inexplicability, the authority of law seems ultimately untranslatable particularly because of the arbitrariness of its power to decide life and death. And through these moments of illegibility, the state "has the capacity to drive people mad" from being "oversaturated with the law" (Berlant, 1991).

In the summer of 2014, Abdel Baseer was with his father in Gamasa after having finished his thanawiya 'amma ${ }^{19}$ examinations. They heard the news of an ambush in El Farafra, and little did they know that Abdel Baseer would be added as a defendant to the case. During the military court hearings, the judge received a copy of his birth certificate, indicating that he was below 18 years at the time of the ambush, and so he assured the defense that Abdel Baseer would not receive "the first two sentences:" either the death penalty or life in prison. His father spoke with me afterwards, still in denial of the news he read: that his son's papers were referred to the Mufti. The verdict was scheduled for the day after, and what occupied his thoughts on the eve of was "how they establish this thing [the law, its sovereignty] to try us by, and let's even assume that he participated in the ambush like they claim, shouldn't they try him according to the thing that they put in place? What are they doing now? They don't want to judge him, not even according to their rules - they want to kill him." The desire to kill, as understood by Abdel Baseer's father, resonates with Aretxaga's (2003) analysis on sovereignty, which "presents itself as the law," yet stands outside it. In this sense, to claim state sovereignty is "to embody a juridical order that cannot be held accountable" (p.405). Realistically, there is no such thing as accountability of the authorities in Egypt. In fact, even the mere passing thought of accountability, of the police, the army, the state security, the judge panel, and even the presidency, is absurd.

\section{The (Intentionally) Irresponsible Paper State}

The Egyptian state discourse is clear about evading its responsibility of producing killable bodies. The arrest of criminals who had received death sentences in absentia features in news reports documenting the efforts of police officers to maintain security. Even then, fantasies about the criminality of such people are enacted. Otherwise, the national discourse is very abstract in terms of the death penalty: while it refers to i'dām - the Arabic version of "death penalty" or "capital punishment," it does not mention death, punishment, or capitis. Rather, its connotation is that of nothingness and void. 20

The procedures potentially leading to a death sentence are also described in similar terms, with no emphasis on acts of killing. The diffusion of the state's murder responsibility is further enabled by the utter bureaucracy of the Egyptian state. The people on trial for a capital crime are reduced to "papers" that are

\footnotetext{
19 High school degree

20 The root of the word is 'adam, which literally translates to non-, nothingness, and void.
} 
juggled between the criminal court and the Mufti with a "shroud of secrecy" (Taussig, 1992) around the content of such document-exchanges. Until 2012, Egypt's Dār al Iftā '21 published an annual report stating the number of "papers" that it received from criminal courts. It was the last publicly-published report - and, perhaps not incidentally, it noted that the former Mufti refused to sign the papers of defendants in 12 cases before him. Since then, the correspondences are secretive, and bear the "state seal" with all the weight of its symbolism. It is quite certainly that, as Hull $(2012$, p.1) describes, a regime of paper documents, serves as a reminder of the power and sovereignty of the nowhere-to-be-found state.

This is brilliantly captured by Arendt (1953), in her description of bureaucracy as the most recent form of domination: it is "the rule of an intricate system of bureaus in which no men, neither one nor the best, neither the few nor the many, can be held responsible" (p.237) for violent state acts, matters of life and death included. In a state of paper, there is no paper trail that would enable pinning the responsibility of producing killable bodies onto someone, because it is primarily, as Arendt (1953) articulates, "a rule by Nobody." This Nobody state is surely the most tyrannical of all, simply since no one would be left "who could even be asked to answer for what is being done" (p.237).

I would like to suggest coupling this "state of nobody" with an understanding that it is simultaneously the "state of everybody." That is, at least in the realm of the death penalty, the fact that no one is to be found responsible has to do with the fact that everybody is to a certain extent. And there are too many state actors - "an excess of statehood practices" - that certainly ensures a diffusion of the responsibility to kill (Aretxaga, 2003, p.396). After the back and forth between the judges panel and the Mufti, the court makes it move, throwing the ball in the court of the presumably more mature judges at the Court of Cassation, who are tasked with "trying the criminal court sentence." With only the eagle stamp remaining on the awaited documents, bearing the verdict to die - silent, blue, and symbolically sovereign - nobody else is accountable; nobody else is eligible to answer for the "state." Throughout this long endeavor, which usually takes up to several years, the lazy state employees are juggling with what in reality are lives of human beings - humans who spend years at a time waiting for the next document, for the next encounter - until it becomes impossible to wait.

\section{Awaiting the State}

The encounters of the eventually-to-be-killable bodies with the state set life rhythms of the people sentenced to death and their families. The Abu El Matameer and Kafr El Sheikh arrests were made in 2015 , and the death sentences were respectively made and upheld throughout 2017. However, I am more drawn towards the argument that time is not only measured in such terms - as in the length of years before the lazy state finishes its lazy work, and hands out "a death sentence with an almost sleepy gesture"

21 An institute "to represent Islam and the international flagship for Islamic legal research," Dār al Iftā' "was "established in 1895 by the high command of Khedive Abbas Hilmi, and affiliated to the ministry of Justice on 21st November, 1895." From official website: http://www.dar-alifta.org/ 
(Foucault, 1994, p.429). In fact, the temporal encounters with the state seem to put forward the theme of passing time as a complex dynamic that is frozen, infinite, torturous, and by all means manipulable by a precarious state.

At its most basic, the state's manipulation of time is apparent in the way it sets the life rhythms of death row detainees and their families, and when it appeals to its sovereignty to manipulate them even further. A person's day on death row, for example, is normally centered upon the hour of tarayyod, or the time allocated for walking/exercise. The families of defendants sentenced to death in the Abu El Matameer case describe the tarayyod as a form of freedom, an opportunity to feel running water and maybe see the clouds. Tarayyod becomes a break from the dark, crowded cigarette-smoked, $2 \mathrm{~m}^{2}$ holding cell, where the only experience of fresh air happens when each person, in turn, pushes his nose through the ruler-size viewing naddāra 22 on the cell door.

It is also important to note the absence of sewage drainage within the cell; instead of a toilet, the three prisoners per cell are given a bucket to excrete in. This affects the daily routine even further, since the three Abu El Matameer prisoners have resorted to fasting in order to regulate their daily need to go to the bathroom. Thus, an added layer, consisting of the fajr and maghrib23 prayer times, shape the day to a great extent. And therefore, a large section of the tarayyod is understandably dedicated to ablution, emptying the nagaasa, or "impurity," of the excrete-full bucket, and filling up water bottles in preparation for the upcoming ablution within the cell. Although of a different context, it is possible that time in the Qanater women's prison death row ward is similarly experienced: a previous (political) prisoner reflected on her time "inside" in a Facebook post that was shared by the Against the Death Penalty page, ${ }^{24}$ remembering that whenever she would come across the death row ward during tarayyod, and before the guards realized she was speaking with women sentenced to death and came to separate them, one woman would ask her if she had any empty water bottles.

Whether or not the bottles were used for similar purposes, there is something to be said about the temporal anguish within the death row cells. Daily life on death row does not make sense in terms of hours and minutes. Time itself ceases to make sense in such terms. At the interplay of boredom, hope, memories, and the very vivid encounters with cigarette smoke and cockroaches, is the brutal manipulation of time.

\section{Waiting for the Visit}

In addition to this daily setup, death row prisoners have a one-hour monthly visit with family members. Perhaps out of its precarity, the state did not set any regulatory mechanisms regarding visitations - the

\footnotetext{
22 The naddara is the small, rectangular opening in the cell door.

${ }^{23}$ This is the duration of fasting: from sunrise (fajr) to sunset (maghrib).

${ }^{24}$ https://ar-ar.facebook.com/\%D8\%B6\%D8\%AF-\%D8\%A7\%D9\%84\%D8\%A7\%D8\%B9\%D8\%AF\%D8\%A7\%D9\%85$472007209568200 /$
} 
monthly visits do not exist in legislation, and so they can be taken away just as easily. When Lotfy arrived at the Borg El Arab prison, he filed a complaint against Emad beih, ${ }^{25}$ the head of investigations. To make him retract his complaint, Emad beih decided that Lotfy's family visit would only last 5 minutes. Furthermore, he declared that any medications intended to reach Lotfy would not be allowed, and so the families claimed the medicine was for someone else, who then smuggled it once it reached the inside of the prison, beyond the two checkpoints.

The interaction with state employees (and beihs) resonates with another rhythm on an annual basis: the head of investigations, or state security officer in charge, is replaced in August. And as Goffman (1961) eloquently describes, a "welcome" awaits the prisoners - this time of the year, though, it is not performed by previous, older, prisoners, but by the new state-figure who must establish his (fantasies of) sovereignty to be feared and respected. Until last August, the state security person in the Abaadiya prison was somewhat sympathetic of the circumstances of the three political prisoners in a death row ward with 97 jina'i 26 prisoners. He spoke with them about relocating them to another ward with an in-cell bathroom and other political prisoners, and possibly made such plans. The "welcome" of his August replacement, however, consisted of a crackdown in which the death row ward prisoners were forced out of their cells, handcuffed, beaten, and had their hair shaved. The contents of their cells - blankets, boxed cheese, water bottles, spare underwear - were taken away, thereby forcing the families to bring more of each confiscated item during the following visit, which was reduced, as of August, to 15 minutes. Even when they did so, underwear became prohibited on the basis that their (white) color, with the new prison "regime" stipulating that the death row prisoners are supposed to only wear red.

As such, family members' visits are precarious as well. To reach the prison on the day of the visit in time whenever that may be: it is decided upon by the state on the door - the family members leave their houses around $4 \mathrm{am}$. That means that they spend a day or two prior to the visit preparing the food, freezing it overnight so that it endures the wait at the prison door. The wait usually stretches till maghrib, sometimes even till the night, until all the visits to other wards are finished. Family members in the Arab Sharkas case interpreted this as the state's way of frustrating the death row ward prisoners: officers walk up to them during the day, telling them no one came to visit. By the time their family members reach them, if they are even allowed in, they are too exhausted from the long wait, having wrestled with the idea that maybe no one did in fact come, and with the infinite possible reasons as to why they might not have come. Some instruct their families to never come see them again. At this moment, the refusal to wait is potentially a way of resisting/refusing the state.

\section{Waiting to Know}

25 This is how the officer is referred to by Lotfy's family members, and how he is referred to in prison, with beih being his title.

26 "Ordinary crime" prisoners, as opposed to "political" prisoners. 
Even before the defendants are sentenced to death, their life rhythms are already contaminated by the state's imposition on their lives, metaphorically but also quite literally, in the sense that they are always waiting for the state: for the next document, for the judge to have breakfast before the court is in session, for the next time they will be allowed to speak before him, for the next chance to describe once more what kinds of torture was inflicted upon them, for the Mufti's report, and for the pronunciation of the verdict. I would like to view these states of waiting, especially the wait to hear the verdict, in light of what Das (2003) calls an "arrest of temporality." This way, each encounter with the state is a time-sucking cycle of illegibility and uncertainty about the moment's outcomes. And in such matters where lives are literally at stake, refusing to wait becomes a way of breaking out of the temporal arrest.

August 7th 2017 was the day of the Mattai verdict hearing - that is, the third one so far after 529 people, including a minor, were sentenced to death in March 2014, then had their sentences revoked by the Court of Cassation in January 2015, only to be tried again before another criminal court in the course of two and a half years. Over 140 prisoners were crammed up in the L-shaped "cage," standing up because they were so crowded that there was no other option, and had been waiting for the judge for at least four hours. Around $12.30 \mathrm{pm}$, there was indistinguishable yelling from within the cage, to draw the guards' attention to the fact that one of the prisoners had fainted. It was possible that he fainted because of the heat, but it is also equally, if not more, compelling to understand his fainting as a bodily refusal of waiting any longer. Until the hearing was over, he had not yet regained consciousness - he was completely out, and the guards, perhaps confused, had not taken off his handcuffs until there was more shouting from the "cage;" a guard immediately uncuffed him, only to cuff one of his hands to the steel bar of a stretcher they had laid him on.

In the same room, but on the other side of the cage, a lawyer was waiting for something else: he had received a call the day before from "someone from the state" who told him the happy news that only eight people out of the 12 who were referred to the Mufti would receive a death sentence. ${ }^{27}$ While all the other lawyers were waiting to hear their defendants' sentences, he was waiting for the judge to be silent after name number eight - and so was I. The judge, however, kept going, naming all twelve people, all sentenced to death - or nothingness - "by hanging until their death." In such moments, the "arrest of temporality" is too intense to endure. Something collapses along with the collapse of time into this infinite present: bodily, emotionally, and everything in between.

\section{Waiting for the Dawn}

The arrest of time is also quite possibly a seemingly infinite expansion of the present moment, such that one loses track of "time" altogether. The passing of time on the death row ward is counted by the number of prayers, as the alternation of light and dark in an always dark place is not enough to "tell" time. "As a general rule," Camus (1961) wrote in his Reflections on the Guillotine, "a man is undone by waiting for

27 This was "happy" to him because his client was not among the initial eight. 
capital punishment well before he dies. Two deaths are inflicted on him, the first being worse than the second" (p.156).

The pain of time, in this sense, is aggravated by the particularity of the Egyptian context, wherein people are not notified ahead of time of their execution dates. It is arguably haphazard, spontaneous, and leaves them infinitely waiting for the dawn when the-state-as-they would come for them. For, according to all the testimonies I have heard so far, they always come at dawn. Consequently, the prisoners' sleep schedules are very disturbed, with some people staying up till $5 \mathrm{am}$, the latest that they could come for them, and then sleeping till the morning-shift employees arrive at 8 am for a new day of encountering the state. Mahy, ${ }^{28}$ who was put in the death row ward just to keep her in solitary confinement in a prison with no solitary confinement cells, met a woman there who had been sentenced to death nine years ago. By the time Marwa left, the woman was still there - she has been waiting for the dawn ever since.

\section{No Longer Waiting}

This temporal pain, the resultant agony of delay on death row, has been cited by the state of California as its basis for abolishing the death penalty in 1972 (Smith, 2007, p.241). Elsewhere in the United States, it has snowballed into a phenomenon of "death row syndrome," of "killing the willing" (Blume, 2005). As of 2005, prisoners who received death sentences from criminal courts could waive their rights to submit an appeal and have to wait for, and throughout, the Cassation trial once more. Therefore, they would essentially "volunteer" for a faster execution (Blume, 2005; Smith, 2007, p.238).

In spite of the contextual differences of the death penalty in Egypt and the United States, it is intriguing to ponder upon this voluntary being-towards-death. Very much in line with Rousseau, it is perhaps the epitome of the cult of confession: for the culprit to endorse his own conviction, to demand to be punished, to long for being killed. In the eloquent words of Camus in his The Stranger (1993, p.111):

If by some extraordinary chance the blade failed, they would just start over. So the thing that bothered me most was that the condemned man had to hope the machine would work the first time. That was the whole secret of good organization. In other words, the condemned man was forced into a kind of moral collaboration. It was in his interest that everything go off without a hitch.

\section{Concluding Remarks}

The state apparatuses that make the death penalty in Egypt not just possible but crudely unprecedented in modern history have a somewhat farcical aura. Morality aside, the processes that appeal to higher notions

28 Pseudonym, with the intention of protecting the source. 
120 of "law" and "justice" and justify the death sentences upon such premises have pretty much nothing to do with either notion on the level of the everyday. Instead, the everyday manifestations of the state, in its relevant officials, employees, and encounters with death row inmates and their families continue to startle: it is as if the state, with all its dynamic faces, continues to consider the production - or mutilation - of ungrievable (Butler, 2009), killable bodies as a mundane task that is just too easy given its perceived superhero abilities and the "the people want it" narratives (Whitman, 2001). Such justification of the penalty as the will of the people is perhaps manifest in the literal pronunciation of the Egyptian court verdicts "in the name of the people." But so many things are lost in this reductionist abstraction, including the pain of time of awaiting and constantly waiting for the state, for being next in line in the march towards death, and for eventually and gradually no longer being altogether. Yet it is exactly those waiting bodies that decide to wait no longer, thereby not only reclaiming "agency," but potentially transcending the worldly conceptions of time, state, farcical justice, and the very gendered appropriation of their bodies and lives. Perhaps it is not merely a personal interest in the machine working "without a hitch," but a dismissal of the entire machine as such. 
Agamben G. (1998). Homo Sacer: Sovereign Power and Bare Life. Stanford, CA: Stanford University Press.

Aretxaga, B. (2000). "A fictional reality: Paramilitary death squads and the construction of state terror in Spain." Death squad: The anthropology of state terror. University of Pennsylvania Press. 46-69.

---a-are (2000). "Playing terrorist: Ghastly plots and the ghostly state." Journal of Spanish Cultural Studies, 1(1): 43-58.

-a--a.-. (2001a). "Terror as thrill: first thoughts on the 'war on terrorism'." Anthropology Quarterly, 75(1): 139-53.

. (2001b). "The sexual games of the body politic: Fantasy and state violence in

Northern Ireland." Cult Med Psychiatry, 25(1): 1-27.

-------. (2003). "Maddening states." Annual Review of Anthropology, 32(1): 393-410. doi:10.1146/annurev.anthro.32.061002.093341.

Benjamin W. (1968). "Theses on the philosophy of history." Illuminations: Essays and Reflections, ed. H Arendt. New York: Schocken Books. 253-64.

. (1978). "Critique of violence." Reflections: Essays, Aphorisms, Autobiographical Writings, ed. P Demetz, Harcourt Brace Jovanovich. 277-301.

Berlant L. (1991). The Anatomy of National Fantasy. Chicago: The University of Chicago Press.

Blume, J. H. (2005). "Killing the Willing:' Volunteers, Suicide and Competency." Michigan Law Review, 103(5): 939-1009.

Butler, J. (2009). Frames of war: When is life grievable? New York: Verso.

Camus, A. (1993). The Stranger. 1942. Trans. Matthew Ward. New York: Knopf.

Conway, D. (2008). "The masculine state in crisis: State response to war resistance in apartheid South Africa." Men and Masculinities, 10(4): 422-439. doi:10.1177/1097184X07306742

Das, Veena and D. Poole. (2004). "State and Its Margins: Comparative Ethnographies" Anthropology in the Margins of the State. Oxford: Oxford University Press. 3-33.

Derrida J. (1991). "Force of law: the mystical foundations of authority." Cardozo Law Rev, 11(5-6): 9211045.

Foucault M. (1978). The History of Sexuality. New York: Vintage Books.

Egyptian Initiative for Personal Rights. (2018). "In the Name of the People: The annual report on the death penalty in Egypt 2017." Retrieved from: https://eipr.org/sites/default/files/reports/pdf/in_the name_of the_people.pdf

Foucault, M. (1979). Discipline and Punish: The Birth of a Prison. New York: Random House.

Foucault, M., \& Rabinow, P. (1984). The Foucault Reader. New York: Pantheon Books.

Freud, S. 1958 (1919). "The Uncanny." On Creativity and the Unconscious, ed. B Nelson. New York: Harper Torchbooks. 122-61.

Goffman, E. (1961). "On the Characteristics of Total Institutions." Symposium on preventive and social psychiatry. Washington, DC: Walter Reed Army Medical Centre. 43-84.

Gupta, A. (1995). "Blurred boundaries: the discourse of corruption, the culture of politics, and the imagined state." American Ethnologist, 22(2): 375-402. 
Kohl 4.1

122 Henyel, G. (2014). "George Carlin - War is prick-waving (The bigger dick foreign policy theory)." YouTube, 14 May 2014. Retrieved from: https://www.youtube.com/watch?v=5qqARrbi1h8

Human Rights Watch. (2017). "'We Do Unreasonable Things Here' | Torture and National Security in AlSisi's Egypt." Retrieved from: www.hrw.org/report/2017/09/05/we-do-unreasonable-thingshere/torture-and-national-security-al-sisis-egypt.

Kafka, F. (1964). The Trial. New York: Modern Library.

Malkki, LH. (1995). Purity and Exile: Violence, memory and national cosmology among Hutu refugees in Tanzania. Chicago: The University of Chicago Press.

Nagengast, C. (1994). "Violence, terror, and the crisis of the state." Annual Review of Anthropology, 23: 109-36.

Navaro-Yashin, Y. (2002). Faces of the state: Secularism and public life in Turkey. Princeton, NJ: Princeton University Press.

Povinelli, E. A. (2008). "The child in the broom closet: States of killing and letting die." South Atlantic Quarterly, 107(3): 509-530. doi:10.1215/00382876-2008-004

Rose, J. (1996). States of Fantasy. Oxford: Clarendon Press.

Sada ElBalad. "المفتي يكثف عن دوره في أحكام الإعدام." YouTube, 16 Oct. 2017. Retrieved from: www.youtube.com/watch?v=0mWVeO_Flnc.

Santner EL. (1996). My Own Private Germany: Daniel Paul Schreber's History of Modernity. Princeton, NJ: Princeton University Press.

Smith, A. (2007). "Not Waiving but Drowning: The Anatomy of Death Row Syndrome and Volunteering for Execution." Public Interest Law Journal, 17(2): 237-54.

Taussig, M. (1993). Mimesis and Alterity: A Particular History of the Senses. New York: Routledge. (1997). The Magic of the State. New York: Routledge.

Trouillot, M-R. (1991). "Anthropology and the savage slot: The poetics and politics of otherness." Recapturing anthropology: Working in the present, ed. R. Fox. New Mexico: The School of American Research Press. 17-44.

--.-. (2001). "The anthropology of the state in the age of globalization: Close encounters of the deceptive kind." Current Anthropology, 42(1): 125-38.

Turner, V. (1974). Dramas, fields, and metaphors: Symbolic action in human society. Ithaca, NY: Cornell University Press.

Zizek, S. (1997). The Plague of Fantasies. London: Verso.

Zulaika J, D. (1996). Terror and Taboo: The Follies, Fables and Faces of Terrorism. New York: Routledge. 